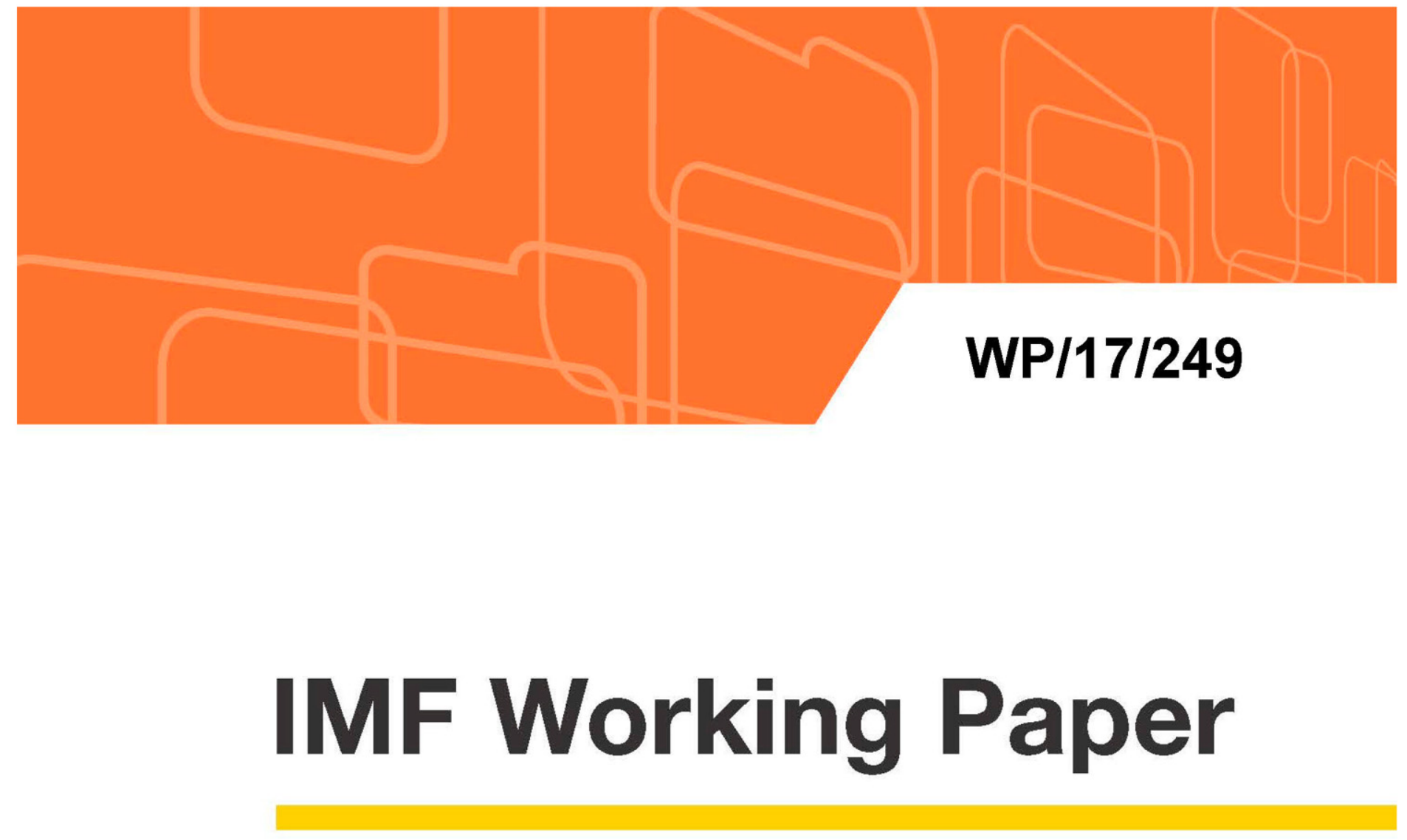

\title{
The Sectoral Effects of Real Depreciations in Latin America
}

by Sergi Lanau

IMF Working Papers describe research in progress by the author(s) and are published to elicit comments and to encourage debate. The views expressed in IMF Working Papers are those of the author(s) and do not necessarily represent the views of the IMF, its Executive Board, or IMF management.

$$
\text { I N T E R N A T I O N A L M O N E T A R Y F U N D }
$$




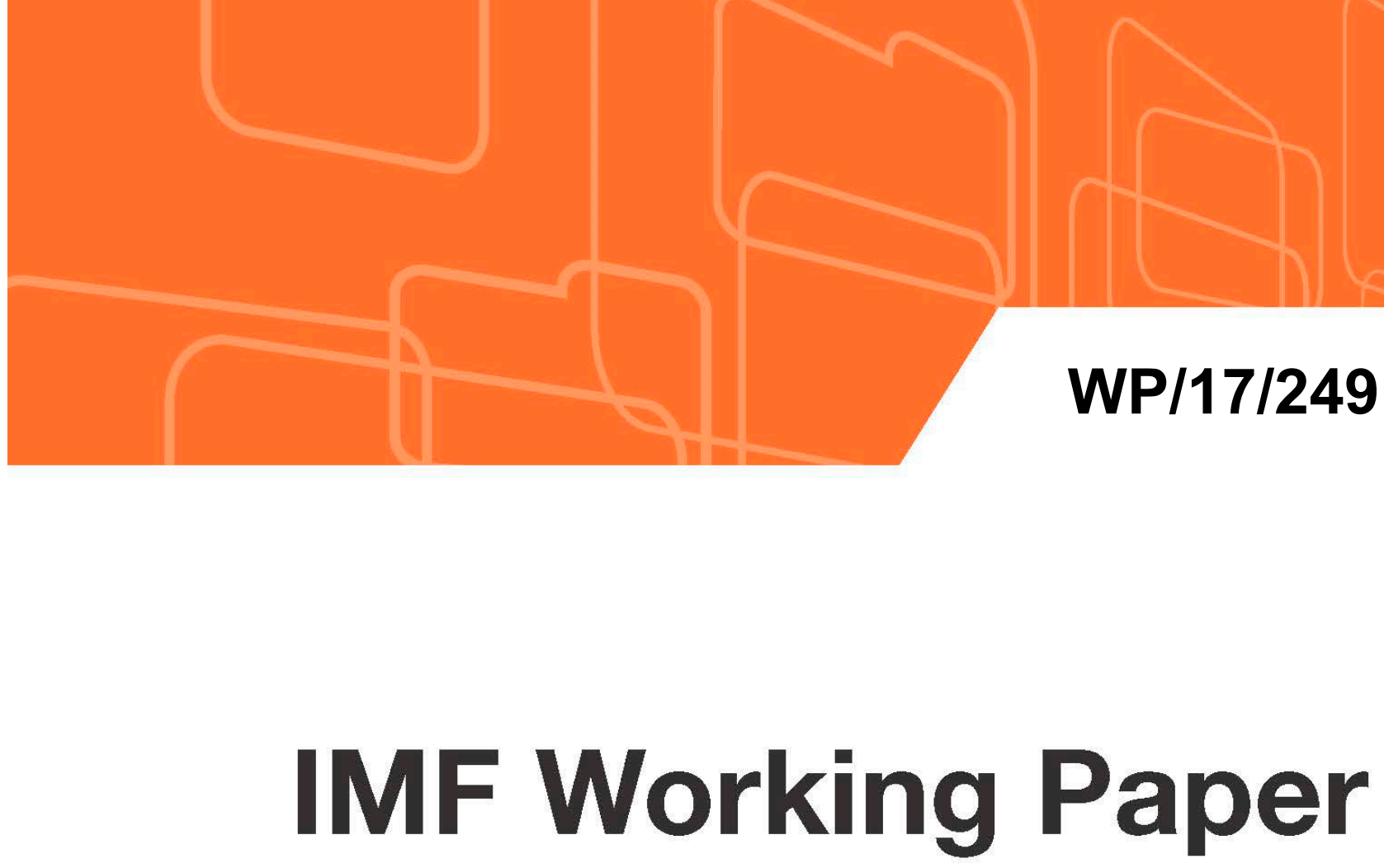

\section{The Sectoral Effects of Real Depreciations in Latin America}

by Sergi Lanau

IMF Working Papers describe research in progress by the author(s) and are published to elicit comments and to encourage debate. The views expressed in IMF Working Papers are those of the author(s) and do not necessarily represent the views of the IMF, its Executive Board, or IMF management.

$$
\text { I N T E R N A T | O N A L M O N E T A R Y F U N D }
$$




\title{
IMF Working Paper
}

Western Hemisphere Department

\section{The Sectoral Effects of Real Depreciations in Latin America}

Prepared by Sergi Lanau

Authorized for distribution by Jorge Roldós

November 2017

\section{IMF Working Papers describe research in progress by the author(s) and are published to elicit comments and to encourage debate. The views expressed in IMF Working Papers are those of the author(s) and do not necessarily represent the views of the IMF, its Executive Board, or IMF management.}

\begin{abstract}
This papers explores the effects of real exchange rate depreciations on growth across sectors, identifying export, cost, and import-penetration channels. It tests the existence and magnitude of these channels in a panel difference-in-difference methodology. Sectors that export more to begin with, grow relatively more in response to a depreciation. The same is true of sectors where import penetration in final demand is higher. There is no evidence that depreciations reduce growth by making imported inputs more expensive. A 10 percent real depreciation would increase growth of nontraditional sectors in Latin America by 0.6 to 2 percentage points mostly through the export channel.
\end{abstract}

JEL Classification Numbers: F14, O47.

Keywords: real exchange rate; depreciation; exports; imports; growth.

Author's E-Mail Address: slanau@imf.org 


\section{Table of Contents}

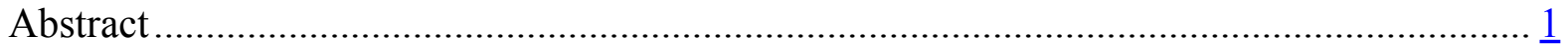

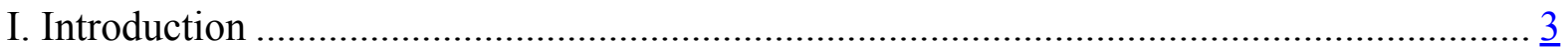

II. Empirical Strategy and Data ............................................................................ 4

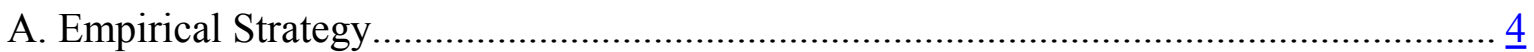

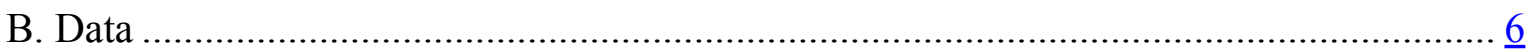

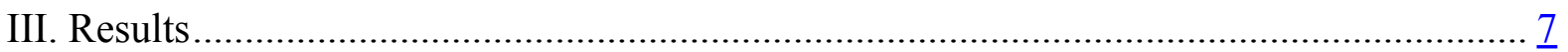

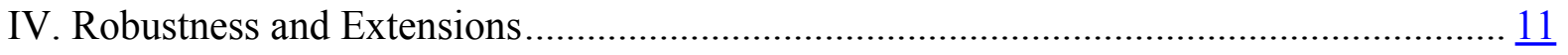

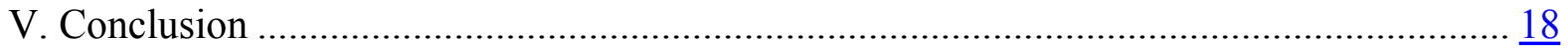

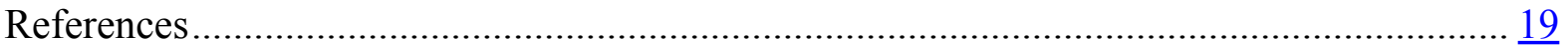




\section{INTRODUCTION}

Real exchange rates depreciated significantly in many major Latin American countries in recent years. These depreciations largely reflected adverse terms-of-trade shocks as a result of sharp drops in world commodity prices. Low commodity prices have been a drag on regional economic growth since 2015 but the observed real depreciations could lift growth by boosting exports and fostering import substitution. This paper attempts to quantify the potential impact of the recent real depreciations on growth in Latin America using sectoral data to identify and disentangle the channels through which real exchange rates affect growth.

Figure 1. Largest Cumulative REER Depreciations in Latin America

(Percent; peak to trough in 2013-17)

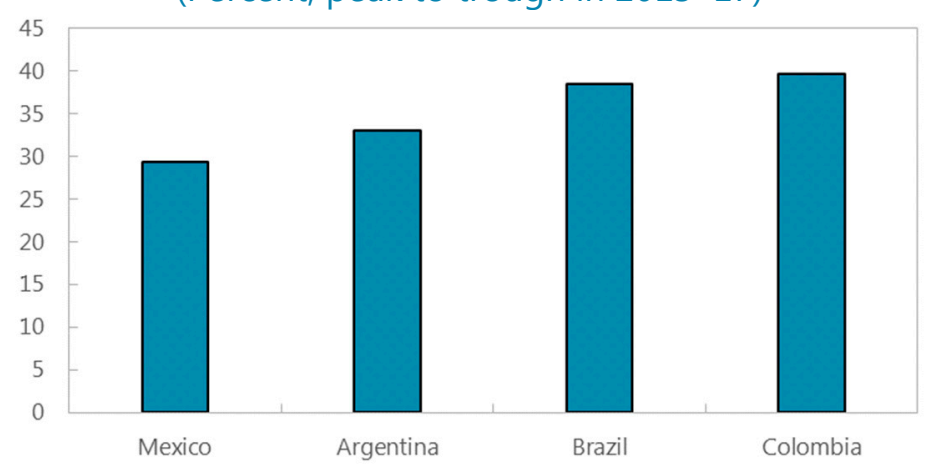

Source:IMFIFS.

The paper focuses on three channels through which the real exchange rate could affect sectoral growth:

- An export channel: Depreciations make domestic products more competitive in international markets and could increase growth through higher exports.

- A cost channel: Depreciations make imported inputs more expensive, potentially reducing growth.

- An import-penetration channel: Depreciations make imported final demand more expensive. If consumers substitute domestically produced goods for costly imported varieties, domestic industries could grow faster.

The analysis tests the existence and magnitude of the three channels in a panel of countrysector-year observations using a difference-in-difference methodology. The analysis is based on annual data from the OECD for 61 countries and 33 sectors for the period 1995-2011. The sample includes Argentina, Brazil, Chile, Colombia, and Costa Rica among the Latin American countries. There are three identifying assumptions, linked to each of the channels above. Following a real depreciation, all else equal: (1) sectors that export relatively more should grow relatively faster; (2) sectors that import relatively more should grow relatively slower; and (3) sectors in which import penetration is relatively higher should grow relatively faster. Any remaining effects of the real exchange rate on growth that do not operate through these three channels are subsumed into a set of country-year fixed effects (which also capture the impact of factors such as real GDP growth and real global growth). Differences in growth 
rates due to country- or sector-specific factors, such as the quality of infrastructure, are captured by a set of country-sector fixed effects.

The results show that the export channel is at work and quantitatively important. Evidence on the cost channel is inconclusive. The import-penetration channel is statistically significant but small in magnitude. A 10 percent real depreciation would increase growth of nontraditional sectors by 0.6 to 2 percentage points over three years (depending on the country), mostly through the export channel. The impact is generally lower than in other regions, but the analysis suggests that real exchange depreciations may help Latin American countries diversify away from commodities and grow in a world of low commodity prices.

The paper relates to a vast body of literature on the economic effects of real exchange rate movements. Recent work by IMF (2017) finds that the export shares of Latin American countries respond positively to real depreciations for noncommodity products. Research on the impact of depreciations on GDP growth has reached different conclusions depending on the sample and methodology used. For example, Kappler et al. (2011) identify 25 episodes of large real appreciations in a sample of 128 developing and advanced economies between 1960 and 2008 and find that the effects on output are limited. In contrast, Farrant and Peersman (2006) show that real exchange rate shocks have a substantial contemporaneous impact on output in a VAR setting. ${ }^{1}$ A few papers including, Branson and Love (1988) and Rodrik (2006) have used data by industry to study the question at hand. Of special relevance is Galindo et al. (2006), who find depreciations improve industrial employment and trade in Latin America, except in industries where liability dollarization is high.

The rest of the paper is organized as follows. Section II describes the empirical strategy and data. Section III present the main results. Robustness checks and extensions are discussed in Section IV. Section V concludes.

\section{EMPIRICAL STRATEgY AND DATA}

\section{A. Empirical Strategy}

The empirical strategy aims at identifying three channels through which real depreciations could affect sectoral growth:

- $\quad$ Export channel. Depreciations make domestic products more competitive in international markets and could increase growth through higher exports.

- $\quad$ Cost channel. Depreciations make imported inputs more expensive, potentially reducing growth.

- Import-penetration channel. Depreciations make imported final demand more expensive. If consumers substitute domestically produced products for costly imported varieties, domestic industries could grow faster.

\footnotetext{
${ }^{1}$ Other relevant contributions in the field include Dollar (1992), Razin and Collins (1997), Freund and Denisse (2008), Di Nino et al. (2011), IMF (2015), and Habib et al. (2016).
} 
I use a difference-in-difference approach to quantify the three channels above. The idea is that sectors that export more to begin with, should grow relatively faster in response to a depreciation. The same concept applies to sectors where import penetration is higher. On the cost side, the opposite is assumed. Sectors that import relatively more inputs to begin with, should grow relatively more slowly in response to a depreciation. The empirical specification is as follows:

$$
\begin{gathered}
\Delta v a_{s c t}=\alpha * \operatorname{Share}_{s c, t-1}+\left[\beta^{x} * X_{s c, t-1}+\beta^{m i} * M I_{s c, t-1}+\beta^{i p} * I P_{s c, t-1}\right] \\
* \Delta R E E R_{c t}+\alpha_{s c}+\alpha_{c t}+u_{s c t}
\end{gathered}
$$

where $\Delta v a_{s c t}$ is the log change in real value added of sector $s$ in country $c$ at time $t$, Share $_{s c, t-1}$ is the lagged share of sector $s$ in total value added in country $c$ (to control for convergence effects), $X_{s c, t-1}$ is a pre-determined measure of how much sector $s$ in country $c$ exports, $M I_{s c, t-1}$ is a pre-determined measure of how many inputs sector $s$ in country $c$ imports, $I P_{S c, t-1}$ is a pre-determined measure of import penetration in final demand for sector $s$ in country $c, \triangle R E E R_{c t}$ is the $\log$ change in the real exchange rate of country $c$ at time $t$ (positive values are appreciations), and $\alpha_{s c}$ and $\alpha_{c t}$ are sets of sector-country and countryyear fixed effects. $u_{s c t}$ is an error term. Standard errors are clustered at the country-sector level.

The coefficients $\left\{\beta^{x}, \beta^{m i}, \beta^{i p}\right\}$ capture the effects of depreciations on sectoral growth through the export, cost, and import-penetration channels. If sectors that export more grow relatively more in response to depreciations, $\beta^{x}$ should be negative and significant. If sectors that import relatively more inputs grow more slowly in response to depreciations, $\beta^{m i}$ should be positive and significant. If sectors where import penetration is higher grow faster in response to a depreciation, $\beta^{i p}$ should be negative and significant. It is important to stress that the framework only captures the effects of depreciations on growth through the three channels above. There may be other channels through which depreciations affect growth, such as foreign-currency liabilities, that are subsumed into the country-year fixed effects. These fixed effects also capture the impact of factors such as GDP growth, trading-partner growth, and any other time-varying country-specific variable.

The variables measuring the openness of each sector are defined as follows:

$$
\begin{aligned}
& X_{s c, t-1}=\frac{\text { Gross Exports }_{s c, t-1}}{\text { Gross Output }_{s c, t-1}}
\end{aligned}
$$

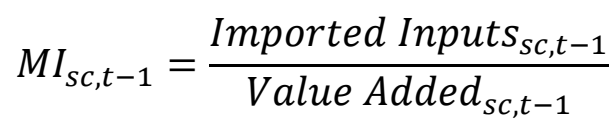

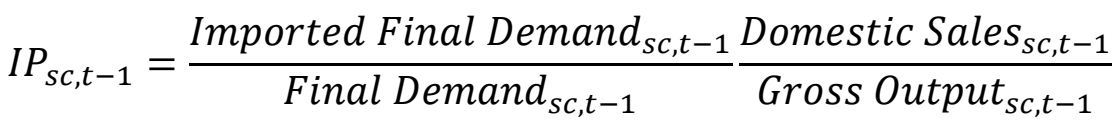


In words, $X_{s c, t-1}$ is the share of gross output that is exported; $M I_{s c, t-1}$ are the units of imported inputs needed to produce a unit of value added; and $I P_{s c, t-1}$ is the share of final demand for product $s$ that is imported times a ratio capturing how domestically oriented a sector is (i.e., the share of gross output sold at home). ${ }^{2}$ Alternative definitions of these terms are explored in section IV. $X, M I$, and $I P$ are lagged one period to make them predetermined and attenuate endogeneity concerns (for example, a depreciation at time $t$ could increase the share of output exported contemporaneously). The results are robust to setting $X, M I$, and $I P$ to their values at the start of the sample.

I also present the results from a distributed-lag version of equation (1) where the real exchange rate is allowed to affect sectoral growth on impact and with two lags:

$$
\begin{aligned}
& \Delta v a_{s c t}=\alpha * \text { Share }_{s c, t-1}+\sum_{j=0}^{2}\left[\beta_{j}^{x} * X_{s c}+\beta_{j}^{m i} * M I_{s c}+\beta_{j}^{i p} * I P_{s c}\right] * \Delta R E E R_{c, t-j} \\
&+\alpha_{s c}+\alpha_{c t}+u_{s c t}
\end{aligned}
$$

In this specification there is a set of six coefficients $\left\{\beta_{j}^{x}, \beta_{j}^{m i}, \beta_{j}^{i p}\right\}_{j=0}^{2}$ of interest, whose interpretation is as in (1). In this case, the ratios $X_{s c}, M I_{s c}$, and $I P_{s c}$ are defined as above but are time invariant and set to their 1995 values.

\section{B. Data}

The OECD input-output tables provide data on nominal value added, gross output, final domestic demand, imported final domestic demand, gross exports, and domestic and imported inputs in dollars for 34 sectors in 61 countries for 1995-2011. ${ }^{3}$ In Latin America, the tables cover Argentina, Brazil, Chile, Colombia, Costa Rica, and Mexico. In the absence of sector-specific deflators for many countries in the sample. the value-added series are converted to local currency and deflated by the GDP deflator to obtain real value added. The rest of the data are used untransformed to compute the ratios described in the previous subsection. Real exchange rate data come from the IMF IFS database. Table 1 shows descriptive statistics.

\footnotetext{
2 The definition of the import-penetration term follows Nucci and Pozzolo (1999).

${ }^{3}$ Australia, Austria, Belgium, Canada, Chile, Czech Republic, Denmark, Estonia, Finland, France, Germany, Greece, Hungary, Iceland, Israel, Italy, Japan, Korea, Latvia, Luxembourg, Mexico, Netherlands, New Zealand, Norway, Poland, Portugal, Slovak Republic, Slovenia, Spain, Sweden, Switzerland, Turkey, United Kingdom, United States, Argentina, Brazil, Brunei Darussalam, Bulgaria, Cambodia, China, Colombia, Costa Rica, Croatia, Cyprus, Hong Kong, India, Indonesia, Lithuania, Malaysia, Malta, Philippines, Romania, Russia, Saudi Arabia, Singapore, South Africa, Chinese Taipei, Thailand, Tunisia, and Vietnam.
} 


\begin{tabular}{|lrrr|}
\hline \multicolumn{4}{c}{ Table 1. Descriptive Statistics } \\
Variable & Mean & Standard deviation & Observations \\
\hline Value added growth & 0.029 & 0.176 & 31,612 \\
X & 0.227 & 0.241 & 31,612 \\
MI & 0.588 & 1.575 & 31,612 \\
IP & 0.098 & 0.616 & 31,612 \\
$\Delta$ REER & 0.006 & 0.078 & 31,612 \\
\hline \multicolumn{2}{l}{ Source: OECD, IMF IFS, author's calculations. } \\
\hline
\end{tabular}

\section{RESUltS}

The results indicate that the export and import-penetration channels are at work in a statistically significant way both in the static and dynamic specifications (Tables 2 and 3 ). The evidence in favor of the cost channel is very mixed, and as shown in section IV is not robust. ${ }^{4}$ The results confirm that: (i) sectors that export relatively more to begin with, grow relatively faster in response to a depreciation; and (ii) sectors where import penetration in final demand is higher, also grow relatively faster in response to a depreciation. The results hold for the subsample of Latin American countries too.

The magnitude of the effects is country-sector specific, as they depend not just on the estimated coefficients but also the openness of each sector. Figure 2 quantifies the impact of a 10 percent depreciation on the manufacturing sector using the coefficients from the full sample results in Table 2. The export channel is quantitatively important in Latin America, especially for Mexico, but generally smaller than the EM average. This largely reflects the fact that manufacturing sectors in Latin America tend to be less open to trade than elsewhere in the EM world. A 10 percent depreciation increases manufacturing growth by 0.1 to 2.3 percentage points, depending on the country. The magnitude of the import-penetration channel is very modest for all countries - a finding that also holds for sectors other than manufacturing.

Figure 3 displays an equivalent exercise for the aggregation of all nontraditional sectors using the dynamic model (Table 3, full sample column). As in the static model, the export channel is dominant in quantitative terms, with effects on impact and with a lag of up to two years. The cost and import-penetration channels have a modest impact on growth. The estimated impact of depreciations on the primary sector is substantially larger but subdued commodity prices cloud the growth outlook for the primary sector in Latin America, making it unlikely that recent depreciations boost growth significantly.

\footnotetext{
${ }^{4}$ The inconsistent signs for the cost channel in some specifications and subsamples may reflect the presence of global value chains.
} 


\begin{tabular}{|c|c|c|c|c|c|}
\hline \multicolumn{6}{|c|}{$\begin{array}{l}\text { Table 2. Baseline specification-Static Version } \\
\text { Real value added growth }\end{array}$} \\
\hline & Full sampl & & AM & EM & LA \\
\hline Imported inputs $* \Delta$ REER & $\begin{array}{c}0.112 \\
{[0.083]}\end{array}$ & & $\begin{array}{l}-0.042 \\
{[0.115]}\end{array}$ & $\begin{array}{c}0.166 * \\
{[0.099]}\end{array}$ & $\begin{array}{l}0.597^{* * *} \\
{[0.111]}\end{array}$ \\
\hline Exports* $\triangle$ REER & $\begin{array}{c}-0.661 \\
{[0.102]}\end{array}$ & $* * *$ & $\begin{array}{l}-0.673^{* * *} \\
{[0.225]}\end{array}$ & $\begin{array}{l}-0.679^{* * *} \\
{[0.112]}\end{array}$ & $\begin{array}{l}-1.189^{* * *} \\
{[0.323]}\end{array}$ \\
\hline Import penetration* $\triangle R E E R$ & $\begin{array}{c}-0.027 \\
{[0.004]}\end{array}$ & $* * *$ & $\begin{array}{l}-0.027^{* * *} \\
{[0.003]}\end{array}$ & $\begin{array}{c}0.006 \\
{[0.033]}\end{array}$ & $\begin{array}{l}-0.096 \\
{[0.257]}\end{array}$ \\
\hline r2 & 0.40 & & 0.55 & 0.31 & 0.20 \\
\hline $\mathrm{N}$ & 31628 & & 12560 & 19068 & 2576 \\
\hline
\end{tabular}

Figure 2. Impact of a 10 Percent Depreciation on Manufacturing Growth

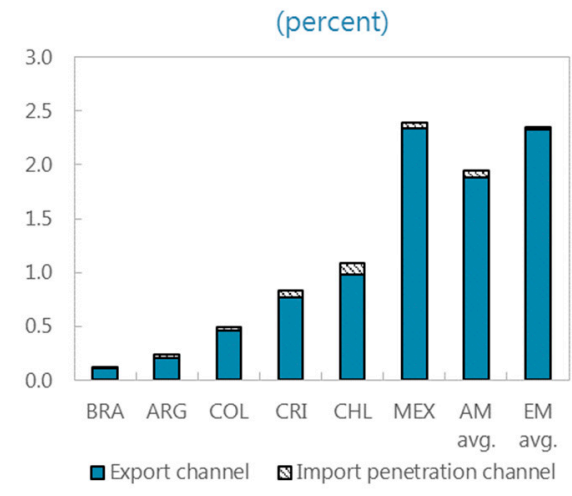

Source: OECD and author's calculations. 


\begin{tabular}{|c|c|c|c|c|c|}
\hline \multicolumn{6}{|c|}{ Table 3. Baseline Specification-Dynamic Version } \\
\hline & \multicolumn{5}{|c|}{ Real value added growth } \\
\hline & Full sample & & AM & EM & LA \\
\hline \multirow[t]{2}{*}{ Imported inputs* $\triangle R E E R(t)$} & -0.006 & & -0.016 & 0.012 & 0.712 \\
\hline & {$[0.020]$} & & {$[0.022]$} & [0.074] & [0.519] \\
\hline \multirow[t]{2}{*}{ Imported inputs* $\triangle \mathrm{REER}(\mathrm{t}-1)$} & 0.032 & & $0.058 * * *$ & -0.097 & $-0.351 *$ \\
\hline & {$[0.030]$} & & {$[0.018]$} & {$[0.064]$} & {$[0.181]$} \\
\hline \multirow[t]{2}{*}{ Imported inputs* $\triangle \mathrm{REER}(\mathrm{t}-2)$} & 0.062 & $* *$ & $0.100 * * *$ & $-0.114 * *$ & -0.106 \\
\hline & {$[0.030]$} & & [0.009] & {$[0.051]$} & [0.128] \\
\hline \multirow[t]{2}{*}{ Exports $* \Delta R E R(t)$} & -0.668 & $* * *$ & $-0.608 * *$ & $-0.713 * * *$ & $-1.955 * *$ \\
\hline & {$[0.101]$} & & {$[0.236]$} & {$[0.134]$} & {$[0.796]$} \\
\hline \multirow[t]{2}{*}{ Exports* $\Delta$ REER(t-1) } & -0.452 & $* * *$ & $-0.388 * *$ & $-0.356 * * *$ & -0.387 \\
\hline & [0.104] & & [0.194] & [0.133] & [0.323] \\
\hline \multirow[t]{2}{*}{ Exports* $\Delta$ REER(t-2) } & -0.391 & $* * *$ & $-0.461 * * *$ & -0.219 & -0.316 \\
\hline & [0.119] & & {$[0.172]$} & [0.137] & [0.192] \\
\hline \multirow[t]{2}{*}{ Import penetration* $\triangle R E E R(t)$} & -0.230 & $* * *$ & 0.013 & $-0.252 * * *$ & $-0.352 * * *$ \\
\hline & {$[0.089]$} & & {$[0.563]$} & {$[0.081]$} & {$[0.092]$} \\
\hline \multirow[t]{2}{*}{ Import penetration $* \Delta R E E R(t-1)$} & -0.117 & $*$ & -0.083 & $-0.126 *$ & $-0.224 * *$ \\
\hline & {$[0.071]$} & & {$[0.556]$} & [0.069] & [0.089] \\
\hline \multirow[t]{2}{*}{ Import penetration* $\Delta R E E R(t-2)$} & -0.001 & & 0.219 & -0.010 & $-0.090 * *$ \\
\hline & [0.069] & & [0.447] & {$[0.068]$} & [0.035] \\
\hline $\mathrm{r} 2$ & 0.40 & & 0.56 & 0.31 & 0.16 \\
\hline $\mathrm{N}$ & 31398 & & 12560 & 18838 & 2576 \\
\hline
\end{tabular}




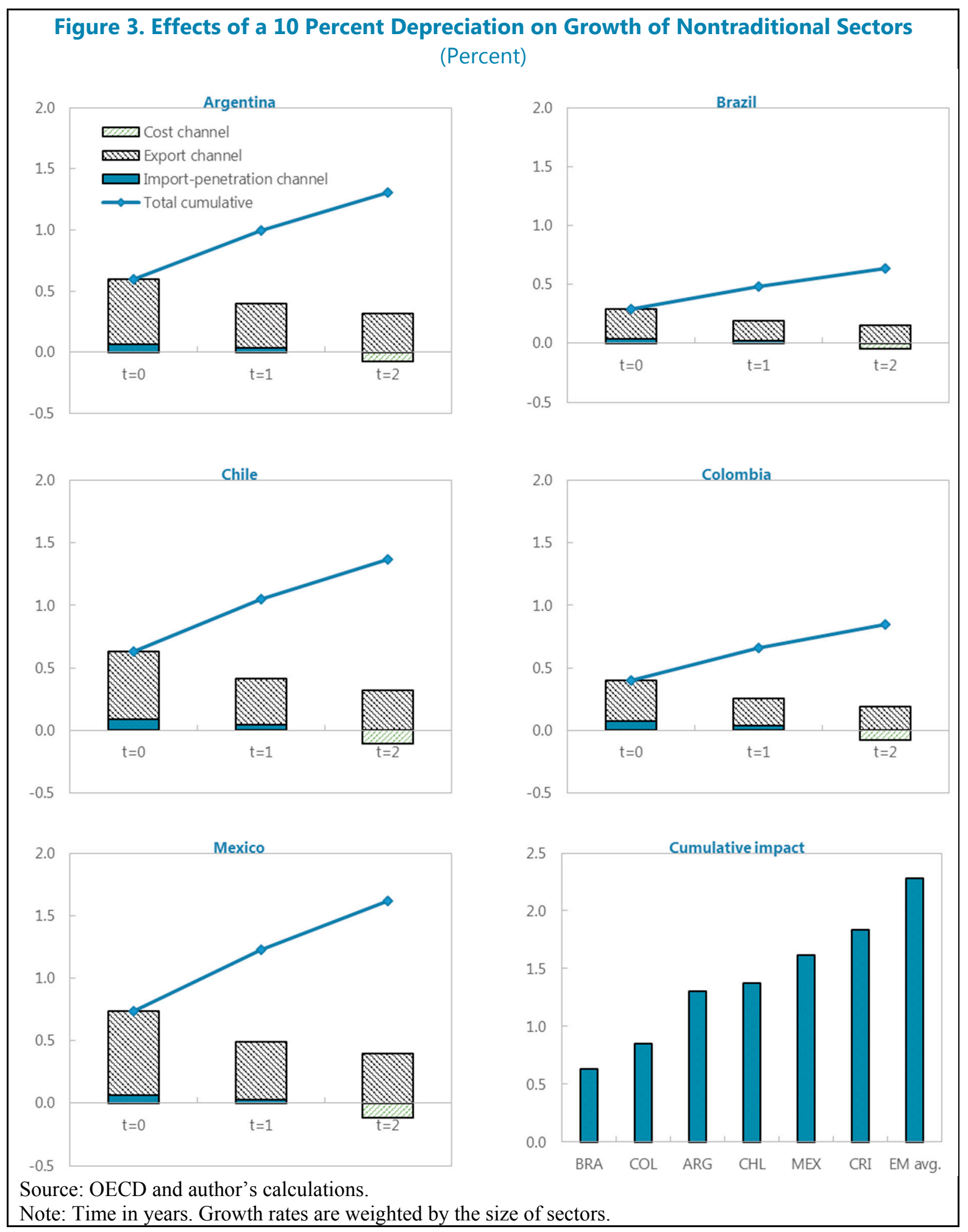

CInternational Monetary Fund. Not for Redistribution 


\section{RobUSTNESS AND EXTENSIONS}

This section addresses the robustness of the baseline results and presents a range of extensions of the baseline specifications. In general, the export channel remains statistically significant and quantitatively relevant but the evidence in favor of the cost and importpenetration channels is weaker.

The cost channel results are not robust to alternative measures of use of imported inputs but the export and import-penetration results remain valid under these alternative cost channel measures. In the baseline specification, $M I$ is defined as units of imported inputs needed to produce a unit of value added but the input-output tables allow for the calculation of two alternative proxies for imported inputs: units of imported inputs needed to produce a unit of gross output and the share of imported inputs in total inputs. As shown in Table 4, these alternative definitions of the cost channel often result in the wrong and significant sign for the cost channel.

The export channel results are robust to an alternative definition of export orientation that takes into account the source of value added embedded in exports. In Table 5, Domestic VA in Exports is defined as the share of domestic value added in exports times the share of gross output that is exported. This term combines the export and cost channels, since an increase in the use of imported inputs reduces the share of domestic value added in exports. The Domestic VA in Exports term is expected to be negative and significant if sectors that export relatively more domestic value added grow relatively faster in response to a depreciation. The import-penetration terms remain as in the baseline. The contemporaneous and lagged coefficients on the modified export channel are negative and very significant, indicating that depreciations boost sectoral growth through exports even when the import content of exports is taken into account. The import-penetration terms lose significance with respect to the baseline specification.

Table 6 explores whether the effects of the real exchange rate on growth last longer than the three years modeled in the baseline dynamic specification. The effects of the cost channel are very significant with a lag of three periods but as discussed above the results are not robust to alternative definitions of use of imported inputs. The export and import-penetration channels are not consistently significant at long lags. The results in Table 6 therefore suggest that the effects of the large Latin American depreciations of 2015-16 should materialize in full by 2018. 
Table 4. Alternative Definitions of the Cost Channel

(Real value added growth)

\begin{tabular}{|c|c|c|c|c|}
\hline & Full sample & & Full sample & \\
\hline (Imported Inputs / Total Inputs) $* \Delta$ REER(t) & $\begin{array}{c}-0.085 \\
{[0.177]}\end{array}$ & & & \\
\hline (Imported Inputs / Total Inputs)* $\Delta \operatorname{REER}(\mathrm{t}-1)$ & $\begin{array}{l}-0.065 \\
{[0.186]}\end{array}$ & & & \\
\hline (Imported Inputs / Total Inputs)* $\Delta \operatorname{REER}(\mathrm{t}-2)$ & $\begin{array}{c}-0.304 \\
{[0.160]}\end{array}$ & $*$ & & \\
\hline (Imported Inputs / Gross Output) ${ }^{*} \Delta R E E R(t)$ & & & $\begin{array}{c}-0.071 \\
{[0.248]}\end{array}$ & \\
\hline (Imported Inputs / Gross Output) ${ }^{*} \Delta R E E R(t-1)$ & & & $\begin{array}{r}-0.430 \\
{[0.246]}\end{array}$ & $*$ \\
\hline (Imported Inputs / Gross Output) ${ }^{*} \Delta R E E R(t-2)$ & & & $\begin{array}{c}-0.422 \\
{[0.216]}\end{array}$ & $*$ \\
\hline Exports $* \operatorname{REER}(\mathrm{t})$ & $\begin{array}{c}-0.655 \\
{[0.110]}\end{array}$ & $* * *$ & $\begin{array}{c}-0.661 \\
{[0.116]}\end{array}$ & $* * *$ \\
\hline Exports* $\triangle R E E R(t-1)$ & $\begin{array}{r}-0.410 \\
{[0.115]}\end{array}$ & $* * *$ & $\begin{array}{c}-0.330 \\
{[0.117]}\end{array}$ & $* * *$ \\
\hline Exports* $\Delta$ REER(t-2) & $\begin{array}{r}-0.256 \\
{[0.123]}\end{array}$ & $* *$ & $\begin{array}{c}-0.242 \\
{[0.123]}\end{array}$ & $* *$ \\
\hline Import penetration* $\triangle \operatorname{REER}(\mathrm{t})$ & $\begin{array}{r}-0.208 \\
{[0.090]}\end{array}$ & $* *$ & $\begin{array}{c}-0.214 \\
{[0.088]}\end{array}$ & $* *$ \\
\hline Import penetration* $\triangle R E E R(t-1)$ & $\begin{array}{c}-0.113 \\
{[0.067]}\end{array}$ & $*$ & $\begin{array}{c}-0.101 \\
{[0.059]}\end{array}$ & * \\
\hline Import penetration* $\triangle R E E R(t-2)$ & $\begin{array}{c}0.024 \\
{[0.080]}\end{array}$ & & $\begin{array}{c}0.020 \\
{[0.077]}\end{array}$ & \\
\hline $\begin{array}{l}\mathrm{r} 2 \\
\mathrm{~N}\end{array}$ & $\begin{array}{c}0.40 \\
31382\end{array}$ & & $\begin{array}{c}0.40 \\
31398\end{array}$ & \\
\hline
\end{tabular}

Note: standard errors in brackets. All regression include country-sector and countryyear fixed effects and control for the lagged share of sectoral value added in total value added. Standard errors clustered by country-sector.

CInternational Monetary Fund. Not for Redistribution 


\begin{tabular}{|c|c|c|}
\hline \multicolumn{3}{|c|}{$\begin{array}{l}\text { Table 5. Domestic Value Added in Exports } \\
\text { (Real value added growth) }\end{array}$} \\
\hline \multicolumn{3}{|c|}{ Full sample } \\
\hline Domestic VA in Exports* $\triangle R E E R(t)$ & $\begin{array}{r}-0.892 \\
{[0.127]}\end{array}$ & $* * *$ \\
\hline Domestic VA in Exports* $\triangle$ REER(t-1) & $\begin{array}{r}-0.539 \\
{[0.130]}\end{array}$ & $* * *$ \\
\hline Domestic VA in Exports* $\triangle$ REER(t-2) & $\begin{array}{r}-0.410 \\
{[0.144]}\end{array}$ & $* * *$ \\
\hline Import Penetration* $\Delta R E E R(t)$ & $\begin{array}{r}-0.202 \\
{[0.089]}\end{array}$ & $* *$ \\
\hline Import Penetration* $\Delta$ REER(t-1) & $\begin{array}{r}-0.091 \\
{[0.069]}\end{array}$ & \\
\hline Import Penetration* $\Delta$ REER(t-2) & $\begin{array}{r}0.020 \\
{[0.070]}\end{array}$ & \\
\hline $\begin{array}{l}\mathrm{r} 2 \\
\mathrm{~N} \\
\text { Note: all regression include country-se } \\
\text { fixed effects and control for the lagged } \\
\text { added in total value added. Standard } \mathrm{e} \\
\text { country-sector. }\end{array}$ & $\begin{array}{c}0.40 \\
31398 \\
\text { r and cou } \\
\text { are of sec } \\
\text { rs cluster }\end{array}$ & $\begin{array}{l}\text { try-year } \\
\text { oral value } \\
\text { d by }\end{array}$ \\
\hline
\end{tabular}




\begin{tabular}{|c|c|c|c|c|c|}
\hline \multicolumn{6}{|c|}{$\begin{array}{l}\text { Table 6. Dynamic Model with Longer Lags } \\
\text { (Real value added growth) }\end{array}$} \\
\hline & Full sample & & AM & EM & LA \\
\hline Imported inputs* $\triangle \operatorname{REER}(\mathrm{t})$ & $\begin{array}{c}0.134 \\
{[0.183]}\end{array}$ & & $\begin{array}{c}0.321 \\
{[0.555]}\end{array}$ & $\begin{array}{r}0.123 \\
{[0.192]}\end{array}$ & $\begin{array}{l}-1.053 \\
{[0.678]}\end{array}$ \\
\hline Imported inputs* $\triangle \operatorname{REER}(\mathrm{t}-1)$ & $\begin{array}{c}0.103 \\
{[0.190]}\end{array}$ & & $\begin{array}{c}-0.143 \\
{[0.567]}\end{array}$ & $\begin{array}{c}0.178 \\
{[0.197]}\end{array}$ & $\begin{array}{l}0.867 \\
{[0.371]}\end{array}$ \\
\hline Imported inputs* $\triangle \operatorname{REER}(\mathrm{t}-2)$ & $\begin{array}{c}0.332 \\
{[0.167]}\end{array}$ & $* *$ & $\begin{array}{c}-0.280 \\
{[0.374]}\end{array}$ & $\begin{array}{l}0.4822^{* * *} \\
{[0.185]}\end{array}$ & $\begin{array}{c}0.443 \\
{[0.257]}\end{array}{ }^{*}$ \\
\hline Imported inputs* $\triangle \operatorname{REER}(\mathrm{t}-3)$ & $\begin{array}{c}0.405 \\
{[0.135]}\end{array}$ & $* * *$ & $\begin{array}{r}0.533 \\
{[0.399]}\end{array}$ & $\begin{array}{l}0.379 * * \\
{[0.150]}\end{array}$ & $\begin{array}{r}0.287 \\
{[0.230]}\end{array}$ \\
\hline Exports $* \Delta R E E R(t)$ & $\begin{array}{c}-0.632 \\
{[0.113]}\end{array}$ & $* * *$ & $\begin{array}{l}-0.523 * \\
{[0.277]}\end{array}$ & $\begin{array}{l}-0.654^{* * *} \\
{[0.123]}\end{array}$ & $\begin{array}{l}-1.600 * * * \\
{[0.597]}\end{array}$ \\
\hline Exports $* \operatorname{REER}(\mathrm{t}-1)$ & $\begin{array}{r}-0.400 \\
{[0.117]}\end{array}$ & $* * *$ & $\begin{array}{c}-0.342 \\
{[0.229]}\end{array}$ & $\begin{array}{l}-0.413 * * * \\
{[0.134]}\end{array}$ & $\begin{array}{l}-0.487 * \\
{[0.293]}\end{array}$ \\
\hline Exports $* \Delta \operatorname{REER}(\mathrm{t}-2)$ & $\begin{array}{l}-0.245 \\
{[0.128]}\end{array}$ & $*$ & $\begin{array}{l}-0.518 \text { ** } \\
{[0.203]}\end{array}$ & $\begin{array}{l}-0.198 \\
{[0.152]}\end{array}$ & $\begin{array}{l}-0.246 \\
{[0.178]}\end{array}$ \\
\hline Exports* $\Delta R E E R(t-3)$ & $\begin{array}{r}0.116 \\
{[0.082]}\end{array}$ & & $\begin{array}{l}0.390^{* *} \\
{[0.198]}\end{array}$ & $\begin{array}{r}0.069 \\
{[0.090]}\end{array}$ & $\begin{array}{l}-0.315 * \\
{[0.180]}\end{array}$ \\
\hline Import penetration* $\triangle \operatorname{REER}(\mathrm{t})$ & $\begin{array}{c}-0.198 \\
{[0.092]}\end{array}$ & $* *$ & $\begin{array}{c}0.029 \\
{[0.601]}\end{array}$ & $\begin{array}{l}-0.224 * * * \\
{[0.086]}\end{array}$ & $\begin{array}{l}-0.4077^{* * *} \\
{[0.122]}\end{array}$ \\
\hline Import penetration* $\Delta R E E R(t-1)$ & $\begin{array}{c}-0.131 \\
{[0.078]}\end{array}$ & $*$ & $\begin{array}{c}-0.134 \\
{[0.586]}\end{array}$ & $\begin{array}{c}-0.138 * \\
{[0.079]}\end{array}$ & $\begin{array}{l}-0.151 * * \\
{[0.060]}\end{array}$ \\
\hline Import penetration* $\triangle R E E R(t-2)$ & $\begin{array}{c}0.031 \\
{[0.085]}\end{array}$ & & $\begin{array}{c}0.432 \\
{[0.486]}\end{array}$ & $\begin{array}{c}0.015 \\
{[0.082]}\end{array}$ & $\begin{array}{l}-0.060 \\
{[0.040]}\end{array}$ \\
\hline Import penetration* $\triangle R E E R(t-3)$ & $\begin{array}{l}-0.084 \\
{[0.078]}\end{array}$ & & $\begin{array}{l}-0.719 * * \\
{[0.362]}\end{array}$ & $\begin{array}{l}-0.070 \\
{[0.072]}\end{array}$ & $\begin{array}{c}-0.001 \\
{[0.044]}\end{array}$ \\
\hline $\begin{array}{l}\mathrm{r} 2 \\
\mathrm{~N} \\
\end{array}$ & $\begin{array}{c}0.40 \\
31185 \\
\end{array}$ & & $\begin{array}{c}0.55 \\
12560 \\
\end{array}$ & $\begin{array}{c}0.30 \\
18625 \\
\end{array}$ & $\begin{array}{l}0.16 \\
2576 \\
\end{array}$ \\
\hline
\end{tabular}

Tables 7 and 8 split the sample by type of real exchange rate change to test for the existence of asymmetric effects in the static model. Table 7 shows that the significance of the export channel emanates from depreciation episodes, while the import penetration channel is only significant in appreciation episodes. The results suggest that exporting sectors in Latin America should perform well in coming years. Table 7 splits the sample by the size of the real exchange rate change using $+/-5$ and 10 percent thresholds. The export channel is more 
statistically significant for large real exchange rate changes. It is not clear however that the magnitude of the effect is larger for a certain type of real exchange rate change. No clear patterns emerge for the import-penetration and cost channels from Table 8.

\begin{tabular}{|c|c|c|c|c|}
\hline \multicolumn{5}{|c|}{$\begin{array}{l}\text { Table 7. Appreciation and Depreciation Episodes } \\
\text { (Real value added growth) }\end{array}$} \\
\hline & Appreciations & & Depreciations & \\
\hline \multirow[t]{2}{*}{ Imported inputs* $\Delta R E E R$} & -0.294 & & 0.132 & \\
\hline & [0.379] & & [0.313] & \\
\hline \multirow[t]{2}{*}{ Exports* $\triangle$ REER } & -0.205 & & -0.813 & $* * *$ \\
\hline & {$[0.203]$} & & {$[0.182]$} & \\
\hline \multirow[t]{2}{*}{ Import penetration* $\triangle \mathrm{REER}$} & -0.021 & $* * *$ & 0.031 & \\
\hline & {$[0.003]$} & & [0.053] & \\
\hline r2 & 0.43 & & 0.44 & \\
\hline $\mathrm{N}$ & 18357 & & 13255 & \\
\hline
\end{tabular}

\begin{tabular}{|c|c|c|c|c|}
\hline \multicolumn{5}{|c|}{$\begin{array}{l}\text { Table 8. Small and Large REER Changes } \\
\text { (Real value added growth) }\end{array}$} \\
\hline & \multicolumn{2}{|c|}{$+/-5 \% \triangle$ REER threshold } & \multicolumn{2}{|c|}{$+/-10 \% \triangle$ REER threshold } \\
\hline & Above & Below & Above & Below \\
\hline Imported inputs* $\triangle$ REER & $\begin{array}{c}-0.350 * \\
{[0.206]}\end{array}$ & $\begin{array}{c}0.719 \\
{[0.564]}\end{array}$ & $\begin{array}{c}-0.188 \\
{[0.310]}\end{array}$ & $\begin{array}{c}0.263 \\
{[0.300]}\end{array}$ \\
\hline Exports* $\triangle$ REER & $\begin{array}{l}-0.544^{* * *} \\
{[0.115]}\end{array}$ & $\begin{array}{l}-0.838 * \\
{[0.434]}\end{array}$ & $\begin{array}{l}-0.597^{* * *} \\
{[0.153]}\end{array}$ & $\begin{array}{l}-0.475 * * \\
{[0.190]}\end{array}$ \\
\hline Import penetration* $\triangle R E E R$ & $\begin{array}{l}-0.033^{* * *} \\
{[0.005]}\end{array}$ & $\begin{array}{l}-0.068 \\
{[0.215]}\end{array}$ & $\begin{array}{c}0.045 \\
{[0.196]}\end{array}$ & $\begin{array}{l}-0.024^{* * *} \\
{[0.003]}\end{array}$ \\
\hline r2 & 0.47 & 0.43 & 0.51 & 0.42 \\
\hline $\mathrm{N}$ & 9820 & 21792 & 2816 & 28796 \\
\hline
\end{tabular}

The final two extensions consider whether the effects of the real exchange rate on growth are different in the primary and non-primary sectors, and EM commodity exporters. The impact of depreciations through the export channel is a lot more relevant for non-primary sectors (Table 9). This could partly reflect the fact that depreciations may coincide with drops in commodity prices, making the growth effects of the exchange rate on the primary sector more muted. Table 10 compares commodity-exporting EMs (as defined in IMF 2015) and other EMs abstracting from differences between sectors. These results bode well for the efforts commodity exporters in Latin America to diversify their export base following the large depreciations of 2015-16. 


\begin{tabular}{|c|c|c|}
\hline \multicolumn{3}{|c|}{$\begin{array}{l}\text { Table 9. Primary and Non-Primary Sectors } \\
\text { (Real value added growth) }\end{array}$} \\
\hline & Primary sectors & Non-primary sectors \\
\hline \multirow[t]{2}{*}{ Imported inputs $*$ REER(t) } & -0.369 & 0.099 \\
\hline & [0.982] & [0.176] \\
\hline \multirow[t]{2}{*}{ Imported inputs* $\Delta R E E R(t-1)$} & 0.874 & -0.058 \\
\hline & [0.857] & [0.188] \\
\hline \multirow[t]{2}{*}{ Imported inputs* $\Delta R E E R(t-2)$} & -1.076 & $0.417 * *$ \\
\hline & {$[0.762]$} & [0.165] \\
\hline \multirow[t]{2}{*}{ Exports* $\Delta R E E R(t)$} & -0.556 & $-0.606 * * *$ \\
\hline & {$[0.370]$} & [0.103] \\
\hline \multirow[t]{2}{*}{ Exports* $\Delta R E E R(t-1)$} & 0.297 & $-0.544 * * *$ \\
\hline & [0.290] & [0.115] \\
\hline \multirow[t]{2}{*}{ Exports* $\Delta R E E R(t-2)$} & $-0.549 * *$ & -0.192 \\
\hline & [0.269] & [0.136] \\
\hline \multirow[t]{2}{*}{ Import penetration* $\triangle \operatorname{REER}(\mathrm{t})$} & 0.101 & $-0.241 * * *$ \\
\hline & [3.766] & [0.091] \\
\hline \multirow[t]{2}{*}{ Import penetration $* \Delta R E E R(t-1)$} & -3.523 & $-0.123 *$ \\
\hline & [2.493] & [0.067] \\
\hline \multirow[t]{2}{*}{ Import penetration* $\Delta R E E R(t-2)$} & -0.756 & 0.020 \\
\hline & [2.892] & [0.079] \\
\hline r2 & 0.55 & 0.43 \\
\hline $\mathrm{N}$ & 2879 & 28503 \\
\hline
\end{tabular}




\begin{tabular}{|c|c|c|c|c|}
\hline \multicolumn{5}{|c|}{$\begin{array}{c}\text { Table 10. EM Commodity Exporters } \\
\text { (Real value added growth) }\end{array}$} \\
\hline & $\begin{array}{c}\text { EM } \\
\text { commodit } \\
\text { exporters } \\
\end{array}$ & & Other EMs & \\
\hline Imported inputs* $\triangle R E E R(t)$ & $\begin{array}{r}-0.245 \\
{[0.297]}\end{array}$ & & $\begin{array}{c}0.454 \\
{[0.263]}\end{array}$ & $*$ \\
\hline Imported inputs* $\Delta R E E R(t-1)$ & $\begin{array}{c}0.421 \\
{[0.264]}\end{array}$ & & $\begin{array}{r}-0.180 \\
{[0.333]}\end{array}$ & \\
\hline Imported inputs* $\Delta R E E R(t-2)$ & $\begin{array}{c}0.772 \\
{[0.323]}\end{array}$ & $* *$ & $\begin{array}{c}0.454 \\
{[0.228]}\end{array}$ & $* *$ \\
\hline Exports $*$ REER(t) & $\begin{array}{r}-0.928 \\
{[0.169]}\end{array}$ & $* * *$ & $\begin{array}{r}-0.445 \\
{[0.168]}\end{array}$ & $* * *$ \\
\hline Exports* $\Delta \operatorname{REER}(\mathrm{t}-1)$ & $\begin{array}{r}-0.422 \\
{[0.141]}\end{array}$ & $* * *$ & $\begin{array}{l}-0.458 \\
{[0.216]}\end{array}$ & $* *$ \\
\hline Exports $* \Delta R E E R(t-2)$ & $\begin{array}{r}-0.231 \\
{[0.205]}\end{array}$ & & $\begin{array}{l}-0.205 \\
{[0.166]}\end{array}$ & \\
\hline Import penetration* $\triangle \mathrm{REER}(\mathrm{t})$ & $\begin{array}{r}-0.261 \\
{[0.175]}\end{array}$ & & $\begin{array}{r}-0.295 \\
{[0.108]}\end{array}$ & $* * *$ \\
\hline Import penetration* $\triangle \mathrm{REER}(\mathrm{t}-1)$ & $\begin{array}{r}-0.156 \\
{[0.174]}\end{array}$ & & $\begin{array}{c}-0.074 \\
{[0.070]}\end{array}$ & \\
\hline Import penetration* $\triangle R E E R(t-2)$ & $\begin{array}{c}0.389 \\
{[0.217]}\end{array}$ & $*$ & $\begin{array}{r}-0.080 \\
{[0.060]}\end{array}$ & \\
\hline $\begin{array}{l}\mathrm{r} 2 \\
\mathrm{~N}\end{array}$ & $\begin{array}{l}0.23 \\
4560\end{array}$ & & $\begin{array}{c}0.33 \\
14262\end{array}$ & \\
\hline
\end{tabular}

CInternational Monetary Fund. Not for Redistribution 


\section{Conclusion}

This paper examines the link between real depreciations and sectoral growth in Latin America by exploiting the variation in trade openness across countries and sectors. The framework tests for the existence and magnitude of three channels through which the real exchange rate could affect sectoral growth: an export channel (depreciations could increase growth through higher imports), a cost channel (depreciations make imported inputs more expensive, potentially reducing growth), and an import-penetration channel (domestic industries could grow faster when a depreciation makes imported final demand more expensive). There are three identifying assumptions behind the empirical framework. Following a real depreciation, all else equal: (1) sectors that export relatively more should grow relatively faster; (2) sectors that import relatively more should grow relatively slower; and (3) sectors in which import penetration is relatively higher should grow relatively faster. The analysis is based on annual data from the OECD for 61 countries and 33 sectors for the period 1995-2011. The sample includes Argentina, Brazil, Chile, Colombia, and Costa Rica among the Latin American countries.

The results show that the export and import-penetration channels are at work in a statistically significant way. The evidence in favor of the cost channel is very mixed. The results confirm that: (i) sectors that export relatively more to begin with, grow relatively faster in response to a depreciation; and (ii) sectors where import penetration in final demand is higher, also grow relatively faster in response to a depreciation. The magnitude of the effects is country and sector specific. The export channel is quantitatively important in Latin America, especially for Mexico, but generally smaller than the EM average. For example, a 10 percent depreciation increases manufacturing growth by 0.1 to 2.3 percentage points, depending on the country. Encouragingly, the quantitative impact is larger for non-primary sectors and for large depreciations. The magnitude of the import-penetration channel is very modest for all Latin American countries - a finding that also holds for sectors other than manufacturing. 


\section{References}

Aguirre, A. and C. Calderon, 2005, "Real Exchange Rate Misalignments and Economic Performance," Central Bank of Chile Working Paper No. 315.

Branson, William and James Love, 1988, "United States Manufacturing and the Real Exchange Rate," in Richard Marston (ed.), Misalignment of Exchange Rates, Chicago: University of Chicago Press.

Di Nino, V., B. Eichengreen, and M. Sbracia, 2011, "Real Exchange Rates, Trade, and Growth: Italy 1861-2011,” Banca d'Italia Economic History, Working Paper No. 10.

Dollar, D., 1992, “Outward-Oriented Developing Economies Really Do Grow More Rapidly: Evidence from 95 LDCs, 1976-85," Economic Development and Cultural Change, Vol. 40, Issue 3.

Eichengreen, B., 2008, "The Real Exchange Rate and Economic Growth,” World Bank PREM Network, Commission on Growth and Development Working Paper No. 4.

Farrant, K. and G. Peersman, 2006, "Is the Exchange Rate a Shock Absorber or a Source of Shocks? New Empirical Evidence," Journal of Money, Credit and Banking, Vol. 38(4), pp. 939-61.

Freund, C. and M. Denisse, 2008, "Export Surges: The Power of a Competitive Currency," Policy Research Working Paper No. 4750 (Washington: World Bank).

Galindo, A., A. Izquierdo and J.M. Montero, 2006, "Real Exchange Rates, Dollarization, and Industrial Employment in Latin America,”, Working Paper No. 575 (Washington: InterAmerican Development Bank).

Habib, M., E. Mileva, and L. Stracca, "The Real Exchange Rate and Economic Growth: Revisiting the Case Using External Instruments," ECB Working Paper No. 1921.

International Monetary Fund, 2015, "World Economic Outlook: Adjusting to Lower Commodity Prices," October (Washington).

International Monetary Fund, 2017, "Western Hemisphere Regional Economic Outlook: Tale of Two Adjustments," April (Washington).

Kappler, M., H. Reisen, M. Schularick, and E. Turkisch, 2012, "The Macroeconomic Effects of Large Exchange Rate Appreciations," Open Economies Review, Vol. 24(3).

Nucci, F. and A. Pozzolo, 1999, "Investment and the Exchange Rate: an Analysis with FirmLevel Panel Data," European Economic Review, No. 45.

Rodrik, Dani, 2006, "Understanding South Africa's Economic Puzzles,” CID Working Paper No. 130, Cambridge: Center for International Development, Harvard University (August). 